\title{
The level of social adjustment of students to the school environment in preventing brawls
}

\author{
Desi Puspita Sari ${ }^{1}$, Syahniar ${ }^{2}$, Yeni Karneli ${ }^{3}$ \\ ${ }^{123}$ Universitas Negeri Padang \\ ${ }^{*}$ Corresponding author, e-mail: desipuspita1901@gmail.com
}

\begin{abstract}
One of the tasks of development in adolescents is social adjustment to the environment which is the school environment. Frequently, adolescents have problems in making social adjustments because this is one of the difficult tasks of adolescent development. If this condition is left, the teen will experience problems. Based on the existing phenomena, there are still students who have not been able to make social adjustments to the school environment so that such things can make students do deviant behavior like brawls. Fighting itself is a fight between groups. The population in this research was the student of SMK Negeri Padang which 140 students were chosen as the sample of the research. The sampling technique used was a purposive random sampling, and the data collection tools used the Social Adjustment Scale (SPS). The data were analyzed by using descriptive statistical methods with data processing using SPSS version 22. The results revealed that social adjustments in brawl prevention were classified as low (50.7\%). Then, in the average, there was $38.6 \%$, and in the high category, there was $10.7 \%$. Based on the results obtained, a follow-up can be carried out by making a guide to improve students' social adjustment to the school environment in preventing brawl.
\end{abstract}

Keywords: Sosial adjustment, brawl

\section{Introduction}

School as an educational institution is a place to develop themselves for students and has an important role in helping students prepare for future success(Azizah \& Hidayati; Mirnayenti, Syahniar \& Alizamar; Nengsi, Firman \& Iswari, 2015). The adolescents is a transition from children to adults. During adolescence,there are changes both physically and psychologically. Adolescence is a transition period, at this time in age, individuals have just separated from childhood which is characterized by starting to show independent behavior such as no longer always dependent on parent(Nurhusni, 2017).

One important aspect that is able to influence the mindset, attitudes, and behavior of adolescents is the environment. Many development tasks must be fulfilled by adolescents to develop optimally, one of which is being able to establish good relationships with their peers 
and be able to adjust to their social environment(Kartika, 2016). Adjustment helps individuals to cope with the demands and pressures of the outside world and their needs and desires. Thus, adjustments help to self-initiated growth and development with intellectual, emotional, and social (Alam, 2018).

Social relations are one of the tasks of development in adolescents. Social relationships among adolescents are influenced by the physical maturity achieved by adolescents. Adolescents who can complete the developmental task will bring adolescents to good social adjustment in their lives, but if adolescents fail then adolescents will experience difficulties in their lives(Yusuf, 2009).

The most difficult task of adolescent development is related to social adjustment. Adolescents must adapt to other people outside the family environment to achieve the goals of adult socialization patterns, adolescents must make many adjustments to the new environment apart from the family environment and school environment(Hurlock, 2010). Adolescent social adaptation to the environment makes adolescents able to get along and can express their views or opinions clearly. Therefore, adolescents are required to have the first and new ability to adjust and can be used as a basis for wider social relationships(Rini, Bahri \& Zuliana 2016). The ability of adolescents to fulfill the tasks of social development will deliver individuals in the ability to adapt to the social environment(Khaira, Firman \& Neviyarni 2017).

Social growth is the most important aspect of one's development and it is acquired through relationships with others especially with parents, peers, and teachers(Yengimolki, Kalantarkousheh \& Malekitabar, 2015). This is in line with the opinion of Sunarto \& Hartono (2011) which explains that one of the environments that adolescents must be able to adapt to themselves is the school environment. This can also be seen from the factors that influence social adjustment itself. One factor that influences social adjustment is environmental factors. There are also among them; (1) parent and child relationships, (2) community, (3) school and (4) culture. A school is a place where teaching and learning process takes place, in schools individuals get intellectual, social and moral lessons.

Some teens may find it difficult to adjust to new environments, especially school environments. This is because adolescence is a period of improvement in self-development, one of which is an adjustment to the new environment (Christanto, Susilo\& Windrawanto, 2018). One new environment that must be adjusted by adolescents with it is to adjust to the school environment. Social adjustment of students to the school environment is a process of adaptation of students to the school environment (Fitri, Firman \& Karneli, 2016). Lakhani, Jain \& Chandel (2017) explain that social adaptation to the school environment plays an important role in the lives of adolescents.

Social adjustment of students to the school environment is an adjustment to subject teachers, peers, and the school environment. Adjustment of students to teachers is influenced by the attitude of teachers in dealing with students. If the teacher's attitude is more friendly and full of intimacy, it will help students to more easily recognize, understand and adjust to the characteristics and personal teacher. Adjustment to subjects that should be adjusted to the age, level of intelligence and needs of students, so students can easily adjust to the subject(Willis, 2005). 
Effective social adjustment is needed by students for the realization of the harmony of student social interaction with all other elements of the school. Scheneider (Azizah \& Hidayati, 2015) revealed that the ability of social adjustment of individuals is needed to be able to interact effectively, beneficial to reality, situations, and social relations. It aims to meet the criteria of the social life of individuals to be accepted in their environment. A good social adjustment is characterized by a good ability to cooperate with others, care for the suffering of others and willingness to help as well as compliance with the values and norms prevailing in the society.

Thus, if students want to develop abilities in social adjustment in the school environment, students must respect the rights of others, be able to create a healthy relationship with others, develop friendships, play an active role in social activities, and respect the valuesof social laws and the culture that exists in the school environment. If these principles are carried out consistently, then social adjustments in a good school environment will be achieved(Maslihah, 2011).

Adolescents who are not able to make social adjustments will have increasingly complex problems. These problems require a solution so as not to become a burden that can interfere with further development. This is one of the reasons why adolescence is considered more vulnerable than at other stages of human development(Hurlock, 2010).

Milarsari (Setianingsi, Uyun \& Yuwono, 2006) explained that many adolescentscan overcome their problems well, but it is not uncommon for some adolescentsto have difficulty in passing and overcoming various problems they face. Adolescents who fail to overcome problems often become insecure, school performance decreases, relationships with friends become poor and various other problems and conflicts that occur. These problematic adolescents then form groups of like-minded friends and engage in negative activities such as student fights (fights), ditching, drinking, stealing, disturbing the safety of the surrounding community and taking actions that can endanger themselves.

The phenomenon in the field shows that students are less able to make social adjustments to the school environment. This information was obtained from a counseling teacher at a vocational school in Padang. The counselor also explained that this happened because students did not respect the rights of others, space to play in small school spaces, dirty classrooms, teachers who sometimes preferred to punish. This makes students prefer to sit in front of the school than in the schoolyard.

The explanation shows that adolescents who are unable to make social adjustments to the environment will face a complex problem so that adolescents engage in negative activities, one of which is fighting. The brawl can be between schools or between certain groups. This is reinforced by the factors causing brawls originating from external factors. According to(Kartono, 2008)many external factors that cause individuals to brawl; (1) family factors (broken household, over the protection of parents, parental rejection, and bad influence from parents), (2) school environment, and (3) environmental factors around individuals.

Based on the data from KPAI (Indonesian Child Protection Commission) published in Tempo.Co on Wednesday, September 12th, 2018, it was noted that brawl cases in Indonesia increased to 1.1\% during 2018. KPAI commissioner for Education Sector Retno Listiyarti said: "last year, the number of brawl cases was only $12.9 \%$, but this year it is $14 \%$ ". 
Seeing brawl cases that occur among adolescents, especially at vocational students, have a variety of impacts both for the perpetrators or victims and even residents around the scene. Therefore it is necessary to conduct a study as a first step to determine the level of social adjustment of students with the school environment in preventing a brawl. This is done because one of the factors in the fight is because the school environment sometimes makes students unable to adjust themselves socially.

\section{Method}

The research method used quantitative and descriptive methods. Descriptive research is research that provides a more detailed description of a symptom or phenomenon(Prasetyo\& Jannah, 2012).Quantitative research methods are studies that use numbers in data presentation and analysis using statistical tests(Saebani, 2008). Quantitative research methods provide quantitative or numerical descriptions and sampling from populations(Creswell, 2009).This method is also called the discovery method because with this method can be found and developed a variety of new science and technology. This method is called a quantitative method because the research data is in the form of numbers and analysis using statistics(Sugiono, 2012).

Population in this research were vocational school student in Padang. The stages of the research began by setting the sample through observation and interviews with the counseling teacher. The research sample consisted of 140 people. The sampling technique used purposive random sampling with the data collection tools in the form of the Social Adjustment Scale (SPS). The data processing to determine the level of social adjustment of students using SPSS version 20.

\section{Results and Discussion}

\section{Results}

Based on the analysis of data that has been done regarding the level of social adjustment in preventing brawl in vocational students in Padang, the following picture is obtained.

Table 1.The Description of Mean (\%) and Percentage (\%) of social adjustments in brawl prevention. Based on Sub variables

\begin{tabular}{|c|c|c|c|c|c|c|}
\hline \multirow{2}{*}{ No } & \multirow{2}{*}{ SubVariable } & \multicolumn{5}{|c|}{ Score } \\
\hline & & Ideal & Max & Min & Mean & Sd \\
\hline 1 & Real Appearance & 40 & 29 & 15 & 20,78 & 3,05 \\
\hline 2 & Social Attitude & 75 & 63 & 31 & 46,26 & 8,18 \\
\hline 3 & Self-Adjustment to the Group & 65 & 51 & 26 & 37,95 & 6,53 \\
\hline 4 & Self-satisfaction & 35 & 22 & 7 & 13,12 & 3,44 \\
\hline \multicolumn{2}{|c|}{ Whole } & 205 & 146 & 90 & 118,08 & 16,46 \\
\hline \multicolumn{7}{|c|}{ Information: } \\
\hline \multicolumn{7}{|c|}{$\begin{array}{l}\text { Max:Highest Score Obtained by } \\
\text { Min:Lowest Score Obtained by }\end{array}$} \\
\hline
\end{tabular}


Table 1 above shows the total level of social adjustment in brawl prevention with an ideal score that is 205 . The highest score obtained by students is 146 and the lowest score obtained by students is 90 which an average score obtained by students is 118.08 and a standard deviation is 16,46 .

Table 3. The Students' Social adjustment in preventing brawls ( $n=140$ students)

\begin{tabular}{|c|c|c|c|c|c|}
\hline \multicolumn{6}{|c|}{ Overall Social Adjustment } \\
\hline \multicolumn{2}{|c|}{ Klasifikasi } & Frequency & Percent & Valid Percent & Cumulative \\
\hline \multirow{4}{*}{ Valid } & High & 15 & 10.07 & 10.07 & 50,7 \\
\hline & Average & 54 & 38.06 .00 & 38.06 .00 & 89.03 .00 \\
\hline & Low & 71 & 50.07 .00 & 50.07 .00 & 100.00 .00 \\
\hline & Total & 140 & 100.00 .00 & 100.00 .00 & \\
\hline
\end{tabular}

Table 2 above revealed that from 140 students; 71 students were in a low category which was $50.7 \%$. Then, in the medium category, 54 students were $38.6 \%$. Moreover, in the high category, 15 students were $10.7 \%$. Thus, it can be concluded that social adjustments in brawl prevention are generally in the low category with which is $50.7 \%$. Thus, it can be concluded that the social adjustment of students to brawls is in a low category. In a sense, it is necessary to increase social adjustment to prevent brawls from vocational students of Padang City. This condition needs to be improved again and acted upon.

\section{Discussioan}

Social adjustment is the ability of individuals to adjust to others in general and their groups in particular (Mualifah, Barida \& Farhana, 2019). Social adjustment is one of the tasks of student development which is basically in adolescence. If the task of development in adolescence is hampered or not fulfilled, then the task of further development will be hampered too (Nurdiana, Siregar \& Arifyanto, 2020).

From the above data, it is known that the social adjustment of students is in the high, medium and low categories. The average student is in a low category. Students who have a low category will have social adjustments to the school environment that is low in preventing brawl. Students who are in the low category will find it difficult to make adjustments to the environment either the school environment or the community environment. Therefore students need good social adjustment skills, so students avoid things that are not desired, one of them is fighting.

The ability to adjust to the social environment or school is needed by every individual. Adjustment leads to the extent to which an individual's personality functions efficiently in society. Individuals who have good adjustments will become individuals who are satisfied with themselves (Hakim \& Mora, 2017). Social adjustment is the ability or effort of a person to consider the standards, values, and desires of society so that individuals can be accepted (Mathur \& Vaishnav, 2017). The ability of social adjustment is an important factor that students need to be accepted in their social life (Suyatno \& Hidayat, 2018). Social adjustment is the 
extent to which adolescents engage in adaptive, appropriate, competent social behavior, and the extent to which adolescents inhibit hostile and incompetent behavior, including the extent to which adolescents mingle with peers (Cai \& Nguyen, 2018).

Therefore, it is needed the role of school personnel who cooperate especially the role of counseling teachers. The need for guidance for adolescents or students to achieve optimal development tasks. Guidance or assistance given to adolescents should be done appropriately.

Based on the results obtained, the researchers followed up by making a guide which is a guide to group guidance in improving social adaptation to the school environment in preventing brawl. This guide can be used by BK / Counselor teachers in supporting the learning process in schools.

\section{Conclusion}

Based on the results of the study it can be concluded that social adjustment to the school environment and brawl prevention is in the low category. There are 71 students in the low category which is $50.7 \%$; in the medium category there are 54 students with a percentage which is $38.6 \%$; in the high category, there are 15 students which is $10.7 \%$. This needs to be increased again with follow-up. One follow-up that can be done is to make a guide to improve social adjustment with the school environment in preventing brawls.

\section{Acknowledgment}

Acknowledge anyone who has helped you with the study, including: Researchers who supplied materials, reagents, or computer programs; anyone who helped with the writing or English, or offered critical comments about the content, or anyone who provided technical help.

State why people have been acknowledged and ask their permission. Acknowledge sources of funding, including any grant or reference numbers. Please avoid apologize for doing a poor job of presenting the manuscript.

\section{References}

Alam, M. (2018). Study of adjustment among senior secondary school students. International Journal of Creative Research Thoughts (IJCRT), 6(1), 47-55.

Azizah, A \& Hidayati, F. (2015). Penyesuaian sosial dan school well-being: studi pada Siswa pondok pesantren yang bersekolah di MBI Amanatul Ummah Pacet Mojokerto, 4(4), 8489.

Christanto, F. A., Susilo, T. D \& Windrawanto, Y. (2018). Effect of self-confidence on high school student's social adjustment. Jurnal Pendidikan Dan Pengajaran, 51(3), 110-114.

Creswell, J. W. (2009). Research design qualitative, quantitative and mixed methods approaches. Amerika: Sage Publications.

Cai, A \& Nguyen, L. M. (2018). Electronic gaming and social adjustment in early school-aged 
children: A twowave cross-lagged design. Thesis.

Fitri, Y. S., Firman \& Karneli, Y. (2016). Efektivitas layanan informasi dengan pendekatan role playing untuk meningkatkan penyesuaian sosial siswa kelas VII SMPN 3 Batusangkar. Jurnal Ilmiah Konseling, 1-9.

Hakim, A. R \& Mora, L. (2017). Keterkaitan regulasi diri dengan penyesuaian sosial di pondok pesantren Al-Amanah Al-Gontory Pondok Aren Tanggerang. Cempaka Putrie Diamala, 2(2), 43-52.

Hurlock, E. B. (2010). Psikologi perkembangan jilid 5. Jakarta: Gramedia Pustaka Utama.

Kartika. (2016). Kesesakan dan agresivitas pada remaja di kawasan tambak Lorok Semarang. Jurnal Empati, 5(1).

Kartono, K. (2008). Kenakalan remaja. Jakarta: Raja Grafindo Persada.

Khaira, I., F. \& N. (2017). Efektivitas pendekatan rational emotive behavior therapy (REBT) dalam meningkatkan penyesuaian sosial anak asuh di panti asuhan Wira Lisna Padang. Jurnal Bikotetik, 1(1), 1-7.

Lakhani, P. K., Jain, K \& Chandel, P. K. (2017). School adjustment, motivation and academic achievement among students. International Journal of Research in Social Sciences, 7(10), 333348.

Maslihah, S. (2011). Studi tentang hubungan dukungan sosial, penyesuaian sosialdi lingkungan sekolah dan prestasi akademik siswa SMPIT boarding school Subang Jawa Barat, 103-114.

Mathur, N \& Vaishnav, R. (2017). Intelligence and social adjustment of joint and nuclear family children studying at high school level, 6(3), 1-4.

Mirnayenti, S. \& A. (2015). Efektivitas layanan informasi menggunakan media animasi meningkatkan sikap anti bullying peserta didik. Konselor, 4(2), 84-91.

Mualifah, A., Barida, M \& Farhana, L. (2019). The effect of self-acceptance and social adjustment on senior high school students' self-concept. International Journal of Educational Research Review, 719-724

Nengsi, Firman \& Iswari, M. (2015). Pengaruh layanan bimbingan kelompok terhadap perencanaan arah karier siswa SMA Pembangunan Laboratorium Universitas Negeri Padang. Konselor, 4(3), 136-146.

Nurdiana, W. O. N., Siregar, V. R \& Arifyanto, A. T. (2020). Pengaruh layanan bimbingan kelompok terhadap penyesuaian sosial siswa di lingkungan sekolah. Jurnal Bening, 4 (1), 45-52.

Nurhusni, P. A. (2017). Profil penyesuaian sosial remaja yang mengalami kecanduan mengakses facebook. Indonesin Journal of Education Counseling, 1(2), 129-144. 
Prasetyo, B \& Jannah, L. M. (2012). Metode penelitian kuantitatif:teori dan aplikasi. Jakarta: Raja Grafindo Persada.

Rini, Bahri , S\& Zuliana, H. (2016). Kontribusi perilaku asertif remaja terhadap penyesuaian sosial (suatu penelitiandi MAN Kota Banda Aceh), 1(1), 13-27.

Saebani, B. A. (2008). Metode penelitian. Bandung: Pustaka Setia.

Setianingsi, E., Uyun, Z \& Yuwono, S. (2006). Hubungan antara penyesuaian sosial remaja yang mengalami kecanduan mengakss facebook. Jurnal Psikologi Universitas Diponegoro, $3(1), 20-35$.

Sugiono. (2012). Metode penelitian pendidikan pendekatan kuantitatif kualitatif dan RED. Bandung: Alfabeta.

Sunarto, H. \&. (2011). Perkembangan peserta didik. Jakarta: Rineka Cipta.

Suyatno \& Hidayat, K. N. (2018). Emotional intelligensi affect social adjustment ability among primary school students. Internasional Journal of Evaluation and Reserch in Education (IJERE), 7(4), 270-278.

Willis, S. S. (2005). Remaja dan masalahnya. Bandung: Alfabeta.

Yengimolki, S., Kalantarkousheh, S. M \& Malekitabar, A. (2015). Self-concept, social adjustment and academic achievement of persian students. International Revief of Social and Humanities, 8(2), 50-60.

Yusuf, S. (2009). Psikologi perkembangan anak dan remaja. Bandung: Remaja Rosda Karya. 